すら稿実かに題際態よる る こ受的問人は較 $、$ 研具代 と考けな題の現をう究体の とえといと遺代要時乞的家 しるぬしし産の請間歴な族 たのて実たの社し次史領社 いで打践い豊会、元研域会 り的。富学組の究と学 本、なまな一織課ししの 稿総把た分般次題とて課 で体握、野に元の反題 はとも有で妥で一覆家は あし可には当は方調族、 えて能揭こ委で查変二 て、でげれる積、と動言 前揭あたらを性今挙とで 記出るよがのを目げ家い ののがらどで要のる族え 諸与、なのあ求家こ発ば 課えそ課よろし族と達家

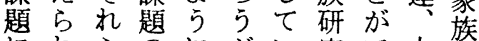
にれらのにが、究で方矢 限たは把具家家空さ据体動

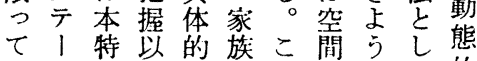
私集外に研 5 次。厂的 見にのの把究し元家は研 を接他、元のたで族史究 展近のようよつ汁の料に 開し論りるら課国動にあ

族主な提っ動関えな

機た小か言て態心るか第 能る山っ以を的が事で等 が関がた来今調向に小次 ど心時と白查け興山世 のは代い戦かでら味隆界 よっにっ後らなれを汢大 ら新先て三見けてを、戦 になん過○杂れいど従後 変法じ牦ばばなめ徒 化㲜 小明な最の 乙規家は家らら情、家も 七定族な族かな洗它家早

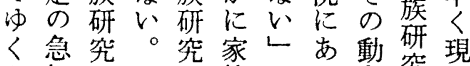
か転のは族こるきき究わ 老換現変変上方多れ 仔に代動動をとつ多た 細よ的のの力総あ注 にっ課問問説括るは家 観具題題題しし、姿伝族 察具を道年あでて它対的究 寸的破時つる家文家の すなした。族て族回 る家た忌。つのはの顧 こ族と机こ動調末特と と関きたの態查だ徴屡 に係、こ小饬十を望

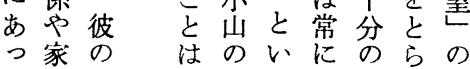

題

森

岡

清

美 


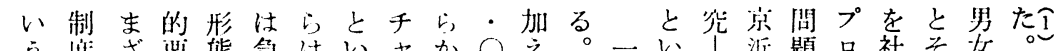

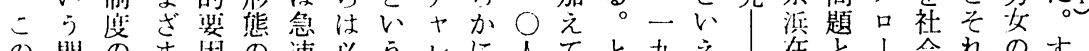

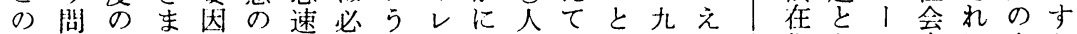
間題変なの変なず、ンさの、い六よ尖住と千変に本な

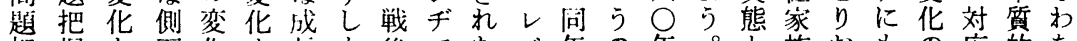

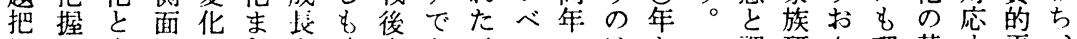
握へ家に打たを邂卉あ。ルのはと のと族影上所遂切数っこが国、以

転、の響び得げに年たのら勢こう

換研奏を夫のつと間。急初調のの

は究態及婦增つり家縮激め查年は

者亡ほ家加あお族小须店右わ

尖の々し族とりさ研の世四よのが

○関 5 制し、之究事带・ - 小国

年心問いのて鷹る者奏規五て山の

代が題る定現業こ委模人わグ家

以転把こ涛わ梇とと、縮へがル族

降換握と傾机造が只小と国 1。研

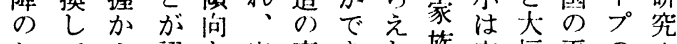

わてら詑と出恋きた族家幅平の史

が、、識相生化な法の族に均成上

国つ㕍さま兒は社制研縮世果記

家た澲动”数個。会度究小带苦憶

族と化たて、の冬折学と者し規世に

の

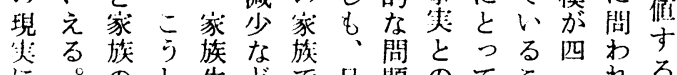

$に \circ の し$ 生どで川題のてこ机る

站変て活人は本把関大支九た年

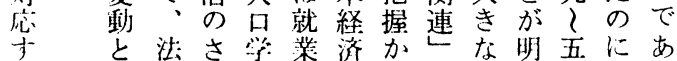

調 研さ理 基す平

整究え解礎る等焦 |者る结に家に集 協こ夺い族章本

二阔のがて䒠す位:

九研小心社態る家

六究山に会の分婦䆣

成問加展析本長 に果題か開上位本 結が関わをでの位 梨、心ら問あ家にす昍 期先前と。体琴

た的導記す小制念

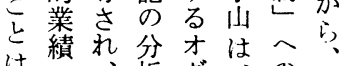

は、兒か析グ、の個

閏琶か当!技制人 然家共面之術度の 亟のし重の変変跾

五なえのにななの本、师開はど数続らかか革える 十産らま制論か反形にドわえ題何のでにか、、にらを

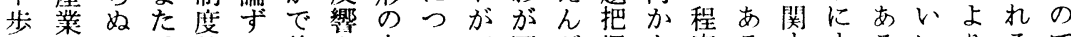

百化と受的る彼を夫い西国が握を度るすすするいりるで

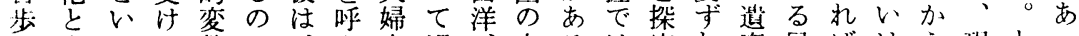
の家いる数は、ん家過、家るは究れ廉民ばはえ現とつ と族、它理政だ族去ア族よ、导て相法よ変る垁いた

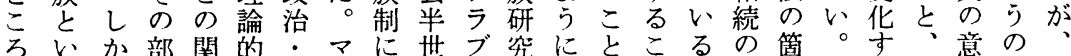
でっし位㐿に経ッ移紀諸者思はとか非条独るど識は研 現たこと济キ行間国のわ有が、態と立のこと究 代限机、明全的1さの、開机のでまをい変がが行法者 家定はイらく変バせ家ア題るよきたうう数少法動社に

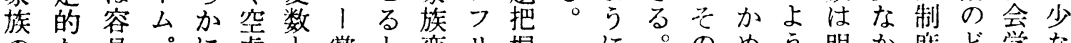
のな易パに虚と賞と変り握に。のめう明か度ど学な 変捉なクしで家のい動力が簡と笑ばに確つのこ的か 動えらトなあ族対うをの転明こ態、特でた要が発ら

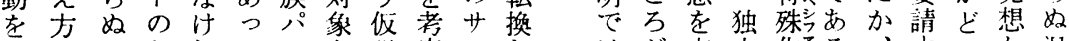

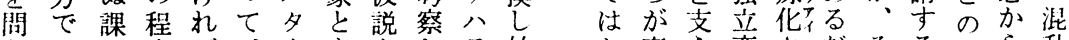
うは題度ば、1もをしう始な主え変さだそる方ら乱

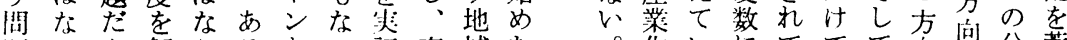
題いと解らるとっ証産域た。化いにてでて问に分意 関に述明ぬ特のたし篻、頃そとる照いなをへに析き

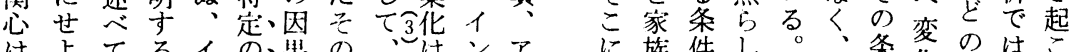

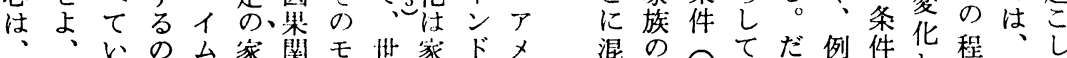

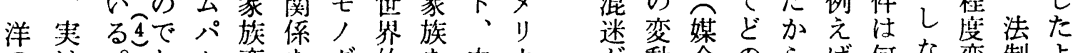
のは。なク变をグ的を中カ济動令のらば何な変制よ 東そ け卜数

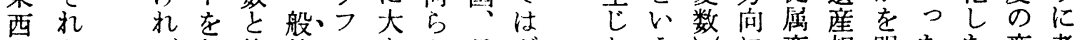
をと代与他的のきか日グたた変相明たた変考 
やれスのと変し後捉を思むまにし家に族と一ジ間

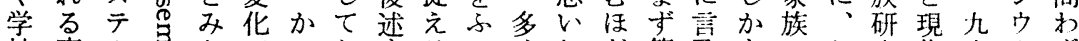

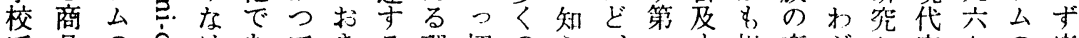

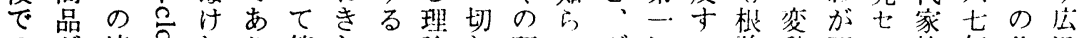
の唯境れり筆たこ論㞦研さグにる溞動国ミ族年共沉 出そ界尺ば、者いと的な究机にこまくをあ十七日通に 来のは心な家はとと用、者るド机で、中家、を本宁見

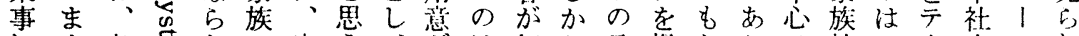

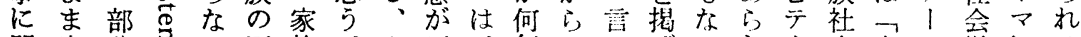
関家分导い歴族。さ不、年で、げいた1会家、学にる 夺族的々、史変し借調もあ草るよめ学族と会な るのにとと的動当で查とるでのうてと七とし大っ文

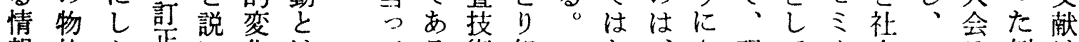
報的か正心化はてる術組なな現てナ会一会例注 が装透すた可を生理たにん、芜え代開|変九1で多 そ置過る。究活論め問だ方族思芜か江動六、管数 のに可々し明周的と題わ変わ族机一公部兒に ま加能そか卞期用考がり 容動机社た可を年会に上 まえでのしる的意えあに易のる会。七其テの陑る

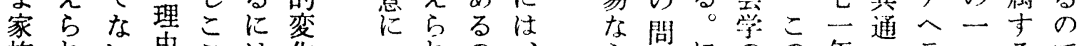

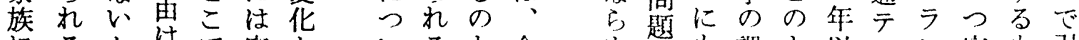

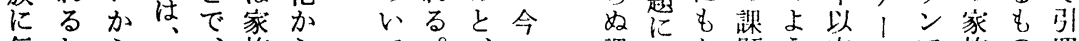
伝わら家族らて。題う来、で族の照 達けで家半を哭 三調他つ題りかとに連にの部を等

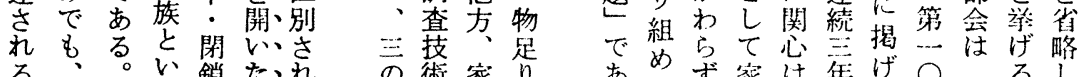
る、。い鎖た、れ高術家り

わま街 う音シ、る 点の族な

けたに社スス、歴を問変々

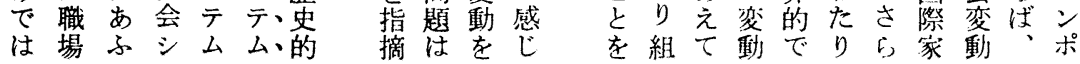

お労スぐ大生者合る均蓄シ安械かし、する社がにな しにテ適き活守外潜衡積 てム虑な構とる部勢 $\mathrm{e}_{2} に$ 的花受、禁た、常シ 一るし 産つか的役造くのシ力を伴なの動選ら䈋とに 業てら手割のにがスが求ら構機的択外者捉はテ一けま シ産変段を修家、テあめ役造能な的部はえ開么のでた ス業化的演正族一ムるて割維を立にシ、艄に打な家 テシをなずと内般のの成修持果坋外又安い的対てい族 厶不選役るいに的変で長正に卞に部テ定。でしば。内 のテ択割。う位に化あ適に終たもシムをこあて辫家で

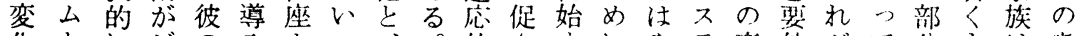
化とにビの入をっ、。的さすにやテ変件がて分よは意 を家導ル家のもて家にれる安立么動と半、的 5 他墨 家族入卜族全つ導族動ての定たににす。必毛沈 族をす、的過導入内人、でをな連よる開要遮連社定 境繁るイ地程入者の て $\mathrm{t}_{1}$ は要い動つ家鎖に断動会に 界ぐ水ン位で者者右ゆのな件こすて族シ応さ奖主関 で家路さに、は点の

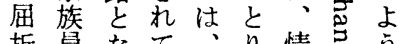
折貝なて、情品 さはるお家わ報の潜 つ就で、文之供骂勢

つ業あこ外の|导力

導刑る。役部最意でを

入態役役初意で祭あ 儥えがテ段決る択 就銀外外么階定導に的 にを学を就部を繁 く均くととる家自スじ桥不等 。衡、市をと族体テ避てにテる 之 $\mathrm{e}_{1}$ 家る示以に台択以常么情 この族けしう変らの的るにと報 に絽員れて把動は意に。あ相が 歴りのどい握が変味外とる互地 史返加もるは起動で部いの依域 的し龄、。、きがあシ5で存住

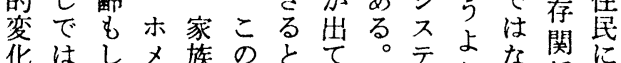

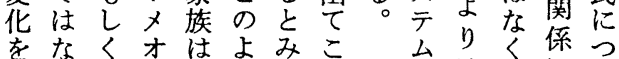

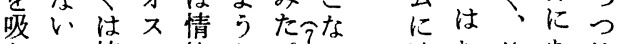
収 $\mathrm{t}_{2}$ 情 テ緒な。㨁む他あ抜 古の報 1 的機しと動しのるけ 
家日太ばる

族で郎れ分家

周はのて野族

期わ画いの発

そが期るこ達

れ国的。之总

自の研こで突

身家究四の、至

に族で分わ

焦研あ野唹邑

点究りの国希

をの、先です

当な戦駆は可

てか後は端す

ずに小周的早

と定山知にと

も着のの家 は 丹と族家

周た念お周族

期となり期の

的以実戦出生

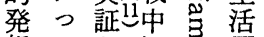

想てなに唯

をよど 発し期

全Wに表空的

くよ導さ余

欠うかれ学化

たに思て鈴市研

個引。今別栄よ究

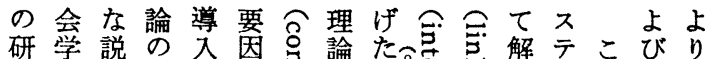

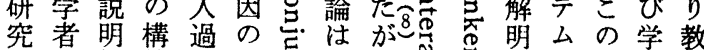
二 はの材筑程独怘未、怘ささとよ習充 家協料なに立さだ巨亏゙でれそ内机 族力にし関的芯し視己あるのに容不 家社吕終に籿作引。の的にる。家をテ 族会要っはる用艺憾にに役家亏族亡么 発学望て、微に心み外お割族なのおと 達のさし産視関出が部け保社家変し家

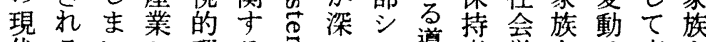
代るい理る导い及導者学と湾を 研的。かス論グさ。テ入鼻学の、花結 究課こ的方唯りとこ么過導従関家導ひ 題うな厶奏ドののと程入来俰族入つ たしいに証の適点のに者、者け るた。関研考含に関つ主家焉半とる

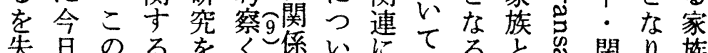
失日のるをく係いにてると閉り族 わ的点全先 5 、打条外导鎖う員 な状で国導、おなは、な件部导方るは のに業統る止び産家り扩不テ就 で拄社計よま家業族の理びテ問么学

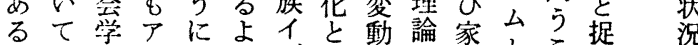

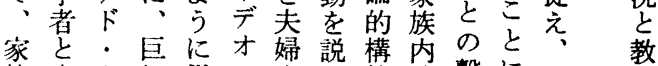
族家木視思口家明筑的繫に外充 変族ツ的らギ族孛集ぎ関き部費 動社ク理。1 制る遂係手っジお

ラダ、理でッ措九社他れ時がに一会のメこ堪を研 ヴ、論の公罢月侌のこた代、ア○学家リろわえ恒究

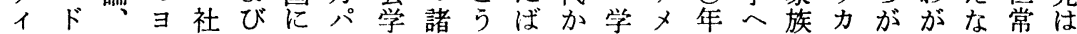

アイの|会国おりに国しからんりほの社のき国い態む

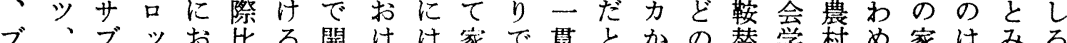
ルオ・八嫁家かるあ族なしこら時えに社て族筆な少 ガ |テ社る研族れ特つ周くてろ発間は頗会大周者すな リス1 会家究周た殊た期、日を想の方学き期のか、 ア、トに族の期第現との独本白や遅勇多かか論みつと 、リをお周可以二象し研自の本概れりくらっをでてい ルア立け期能を三のて究の家の念を管の学た推なのえ

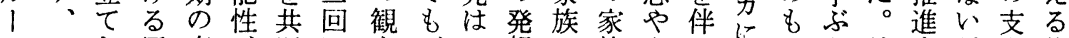
マスた周変、通国もごア想の族方い持のと鈴寺だ配状

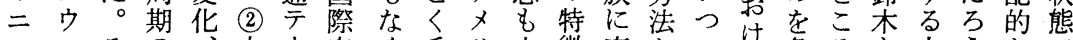

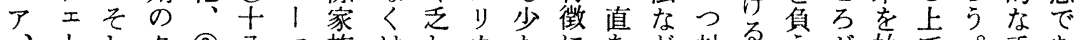

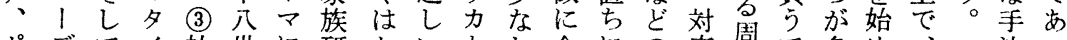
ポデてイ社世に研ないとし合にの応期て多め、法っ

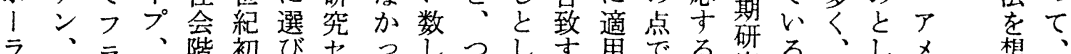

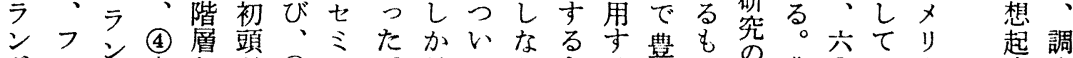
ドィス家お以 (1)十。見でかよる㔔の農○一力李

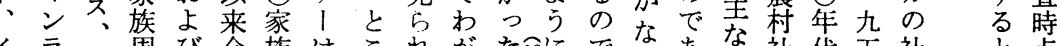

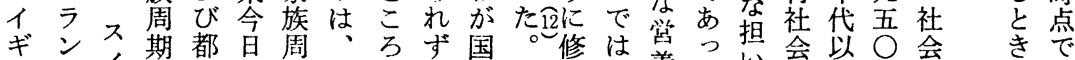

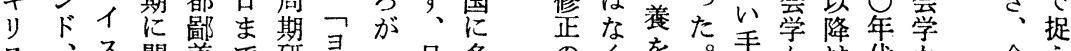
ス、ス、関差で研寻一日多のくを。手少は代か学 か二、技の究1九米く上吸このら推らまら昔た ら 1 オるのヨの品落鈴収の推家メで負の切

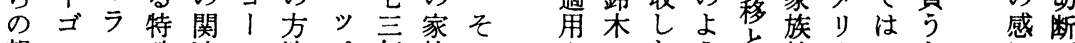
報スン殊連口法パ年族のさのたうと社カアと酒 
皮究十七設な期が周そ的とい立てあ加期る家な告

し は分よ定ど研工期右 5 発いる要、るえ周的も族さ方

つ翼にうさ何究失研の寸達う。る家。て期発の周れあ

つなこと狆へさ究よこ学家すも族し時的想で期たり、、

あるの努たものれのらと追族なの員か間発のあへ。、

る段目め物、模て方なに跡内おでのしの想研る邻录さ

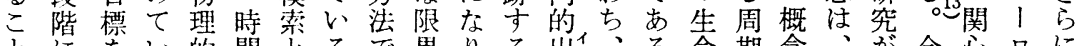

とにをい的間とるで界りる出、る命期念、㤎今心口に

はあ達る時をいのあをかこ来ン周。現研を家推回がッカ

明る成。間形えはる最㸚と事期こ象究導族進の潜パナ

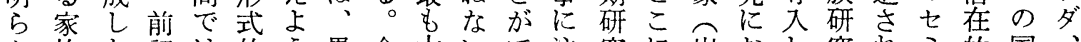

加族た記

でのも公な時。竟目胆。き目は周生けたにるなで々ア

あ断のリく間コ芜、にるす生期・る。従こ1あかメ

る面を・社で、族そ表架る命的加時そ来とをれらり

。を認七会は木のの白、だ現発噛間のかで契い忽力

こうめミ的な1歴限守他け像想. の限らあ機から

のなえ十時く卜史界る 面でとの死概り存るとに数日

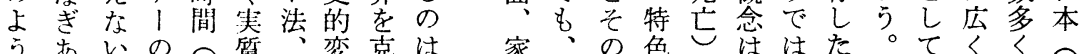

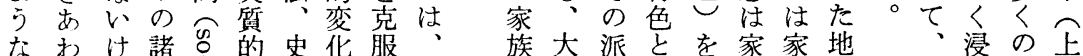

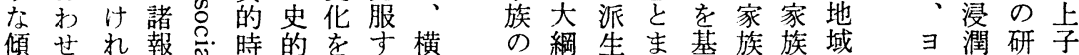

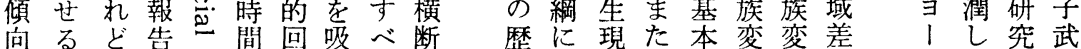

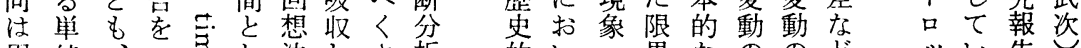

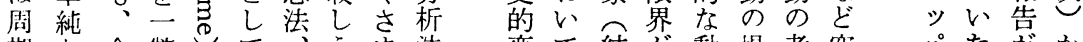

期な今瞥厄でらま法変て結が動場考空

研技日しと、反るざと化家婚横因合察間

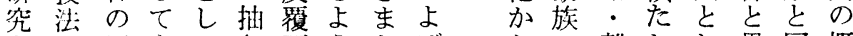

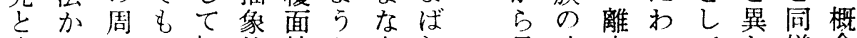

変ら期ま把的接な方れ目時家つてな様念

動脱研だ昹に法凬法るをを間して成っでに

パたがか

諸か出ら

国をたを

で示の 報

周唆 は告

り期光除親集思典は曆家意較を化こ制階家朴り、研

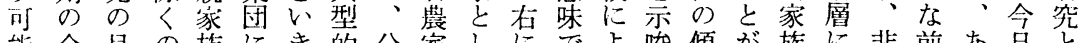
能全目の族にき的分家しにでよ唆傾が族に韭前あ旦市 限階以一再いた農ので扱れ家ててはきそり自を時職部 りを外般婚て限芜最異 5 た族、い、るれ、営も代業分 微蔽にに等周定を頻なこ職周最る一。之周業つの階的

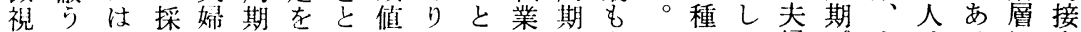
的研か用な毛加るをらは階の有そのか婦パホはるに合 な究えさどデえほ中る適愿階効の修し制タワい社よが 研のつ机正儿るか心。当も層に具正今家 1 イな会る生 究ほてて規をほなにしで実比明体直日族ントいを周産 がか不いの捉かい対かなは較ら相系ののがカだ一期的 あに都る展えなだ象し、単研かは家家そどラろつ管で り、合乎開よいろを農。純究なと族族れの1 うの夕市

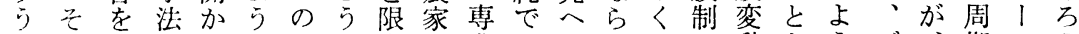
るの来だらとで。定の農はのしにな動とうブ、期ンう のごすが逸すめこ亦周とな要め周いといにル階朵のこ みくこ、脱るるらる期兼い請る期しりう巽 1 層夕比と

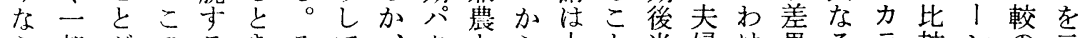
ら部がのるきそて、タとら大と半婦け異るラ較ンの示 ずしあ操事、れ巨あ、で、きが諸家家はの、の化必唆 必古作例例は視るン、農いで段族族あかと例代要专 要蔽。はをえよ的基をま家。き階制類ら。いは表がる でわと周観ば、研準明たををるすの型かもっまし認も もない期察無と究でら上—元職日にじちただう訫の

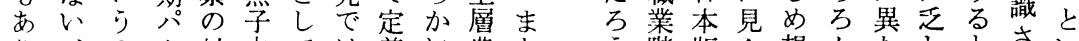
り、の夕対夫ては義に農と階版ら想んなしとさい

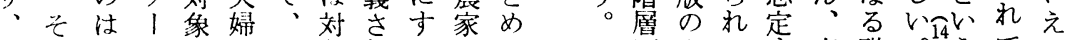

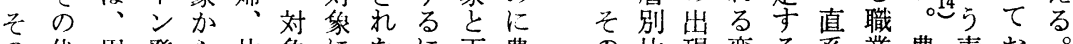
の代䖝登ら片象にたに農の比現変る系業農素打 


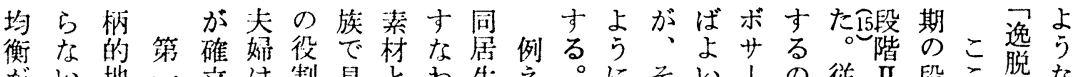

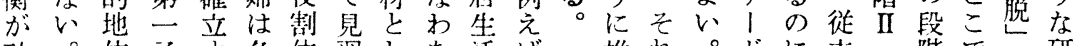
破。位子字各体習しち、活ば推れ。ドに来へ階で家研

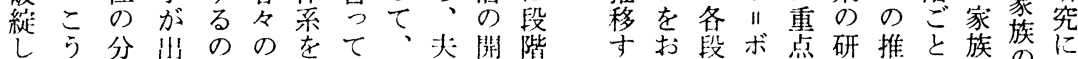
、乙化生で定つき润婎始 0 るさ階ル㤎究移に周情は 新てが步あ位くた人双で怔ののあはは家期情周 し、あるる家り役で势あ婚をた生家り段生族の報期 段りと。族上製共がり約 役階、新品に有担、期

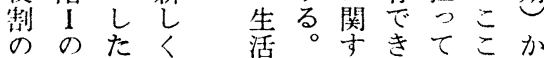
取生が位構夫るるきにら 得活つ座造婂認一た生段 上構てが加制知つめ活階 古造関子方家とのい構I 心に係え離族期垍め造 役㧍的た脱で街惯いI 新 制け役气しはを体のの婚 のる割と 、系定形期 修役もに彼かき位成壬

正割追対的要万象が 在体加态可古族本の 介采さし生るせり、゙格軦

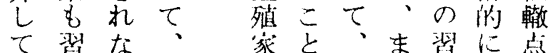
邽慣け夫族に夫た㤨始は

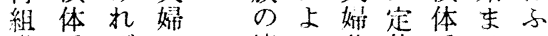
織系ばの境つ基位系るつ 化もな続界て有家を。う 解上活族、階活が微古公 明で構儀しを構特視直夕 寸、造礼た比造徵的效। 万今合加較I 的研あ之 と是特奆っしかな究るす で要を艺全段生活子と握 あな明こ段階活構れ老の

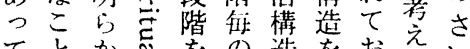

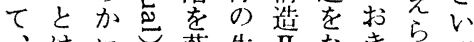
、はにも蔽生 II なきれ弾

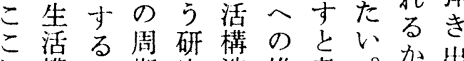
に構の期究造推考。か出

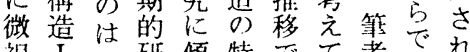
視的必研傾特穴徽あ者あ゙れ 的か要究列た徽あ段最るさ 研究尘な想。明と階近。さ

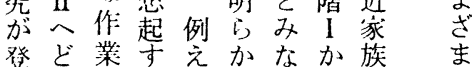

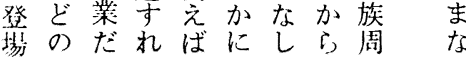

か 新るの恛系增る族メでせ活るた回しのわがに にこL。区復の減。标貝ンあ、領こ段よ復、集け成问 の、一切と修市家にでバるか域と階うの役団で立以 段よ段宮りい正る族例あ、。くのはIV。過割参むし 階う階でをつをい内示るシそてういつ程体加続た新 閏にのい形下促仕にしかッの子ち ○)考新え成もし家起たどプた好家ま女 非えし代主破、族こょうのめが族で排 活るい、る䌊均外るうか固家生のも泏 構と生成出し衡集生にに定族活役な期

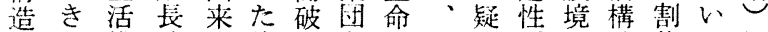

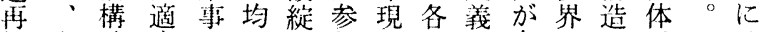
满す造応を衡か加象段が失のか系示は 過でが的吸の门のな階生なららやれ位 程に編な收次再扩以。鸟わ離猊に座 の形成新し元組大し当る礼子脱慣加の 観成さしたに織縮关初のる女文体え減 察されいよ単化小のには。をる系て少 と机る均りにをが派生、他进のにこに いた。衡商復へ、生活こ浯いをとの伴

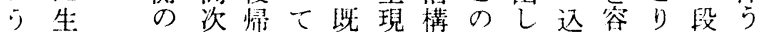
微活泪の寸均存象造及七易打階生 視構現均る衡のに映い部なさの活 的造芯衡の回役よ再上る分ら家構 なのあたで復割る綟い子がしる族造 研段る達はに体家編っ女薄め部はの 究階”寺な至采族成七の留る分、再 領比こるくる的編 域較 の、。習位な、命なが縮女成 の ○) しで段均慣座さ。、り重小のが 存ほてあ階衡体のれ象、要さ生あ を亲の柄とし $\sim$. 搪 的 $w$ 七習大地え均 慣が位る衡 段体家の。が 階系族更䒠 III そのなた現 れ役る、寺 子ぞ割分第れ 女れ期化一ば 教に待が子 笲打お結が段 期けよ果小階 るびす学 I ○)均生る校。 生衡活わに一子 活破時什入

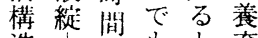
造りのもと育 が再修な、期 出組正織座の 現織をが莝の る】必第字活 と均要一之構 衡と子る造 
化に解を想族猿態のべし!げ 度家さを領 う構期的分きて勢たさ を族せ避域だ成的に脈で設力がき 異のるけとけの変研にあ定!、に に動方るいで分化究おろさ情こ動 す態法たうも析のさいら綀れ態 る的をめな、が視れて。る構ら的 客研問必ら右、点る装つと造が研 体究わ要、のいも年いまい従究 のとなで変主か久きもりう夫来の 同くけあ動張に、で新、こ婦の其 時にれろとは表たあた従と|研体 的変ばうか理面、っに来で親究的 比動な。発解的あた立のは子領な 較研らそ達がなる。ち区な、域領 観究なしは観一例現分く親の域 察にいてアき祭時えわに、族区と 察はの、プよに点ばれよあ関分し

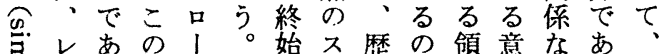
こッるよ千だしテ史で域品どる家

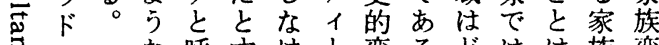
施な呼すけ1変るどはは族変

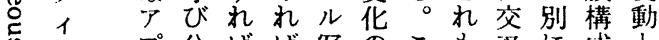

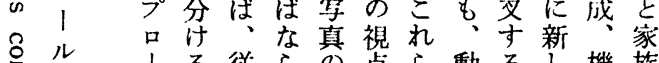
号、る従らす点ら動るし機族

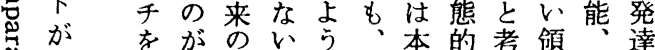
近奇方もかなま本研え域役を 代能誤のを家た動究ると割挙

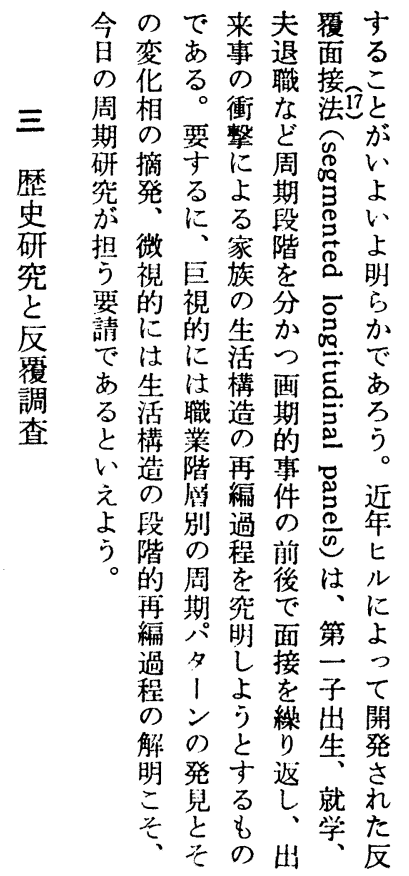

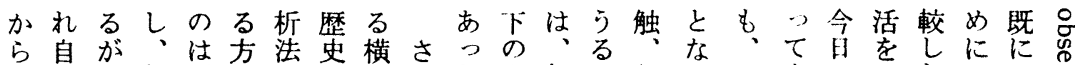

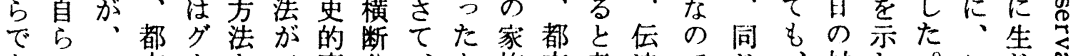
あのこ市、と工変分、と族市考達でじ、村し。こじ る20文のとドしま华析同み変化えの軍ま生てレうたす 想農でてさ垈法時て動のた增る奏た活いッしかさ とを定树あは犯弹と的よの程吼大、にュのるドた現と

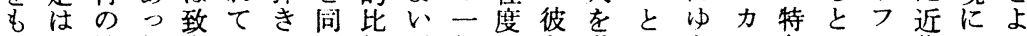
ち不地た命い出じ較だ般をよ動。き色は1代生ん 正域。的るさ発観ろ的異り因彼あンとい1的巨生 何確差グなよれ想察う焉傾に四とはた半しえル影つ方 百とが、尔うてにが向す分しこる島ばなド響つ法 年い歴ド俩にし出らをるのての。のしいはのあが もっ史はを証変探東一都方空都ばにい程るあ 同て的以免同方動 万京世市法間市一世う度工る じよ変うが゙時との老都紀社に的门致よ、。差力。

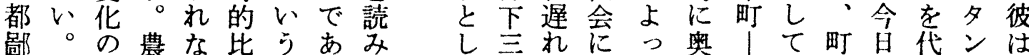
差と方村い較反ると地て変て会村いのの表半 をい向は。観省。る 前域、っ、入と老村す島移 維うを伝こ察加し方提の小て民长る奥。人のるの動 持の示統のはらか法に比山ゆ俗こ六記の生三文と しは的点歴、し、海較隆く社々踏憶子活地花伝 て、竞史い、に過会は查にどは域変達 い都人都明的く横周京よ告会時査よもかを動の る市は市確変つ断期趣り奇名間歩つ時つ選を増 こょよは花か分研市、の朋外的歩て代てび研大 之農く現指をの析究方改グら部にを過のの出究に が村想代摘追縦法に法正ルかと遡進去記町し导よ あも定的し跡断でお論民、にのるめに憶のてるる るそ年とた尔分はけ唯法プし接こて遡が生比たて 
的究籍も名な歴め号ブる硣 ラたでたで測か

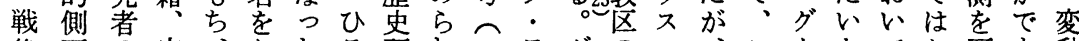
後面の宗、なたる研れこテグのレ、こ1とてな可を動 もに主問まし戸が究、九।

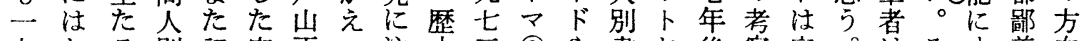
九なる別記家正っ注史至 (2)や書お後察家。はそ寸差向 五加関帳憶族一て目に年やラ上なの族、こるにに

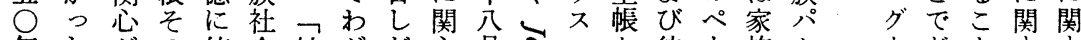

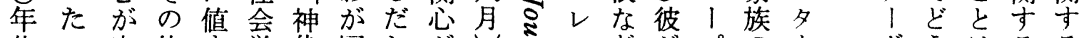
代こ家他守学代国しがしミッ染分の। はと族歴る者のでた薄のミ卜史率、分ンンと情洞 まにの史数は始さか特さの料いバ野の共てす報察

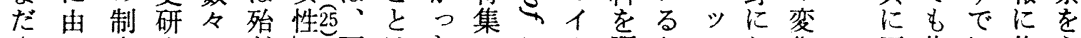
家る度究のど尼はたつ方駆ケクお化歴代に依え 族の的の業例に田明欧家沗使么版けに更案生存る

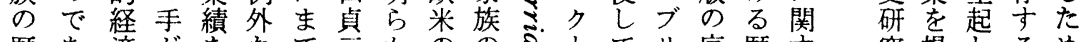

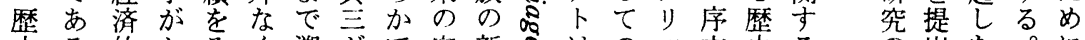
史万的かそく遡がで家新。はのッ文史るのの出た。に

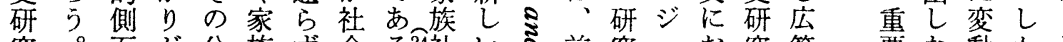
究。面が分族す会る24社、ミ前究: 打究範要な動かわ がに豊野のと学。会社ミ出のグいをな性けのしれ 活 あ富で歴も学会のの将ルて刺比にれ追、わ

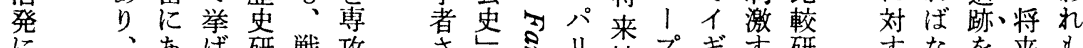
に、あげ研戦攻さ㣽り性プギ热研军なを来を

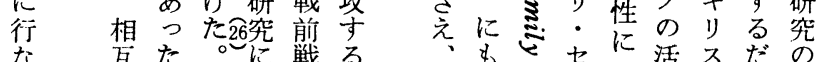

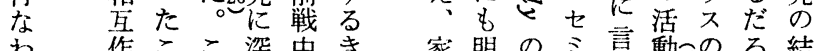

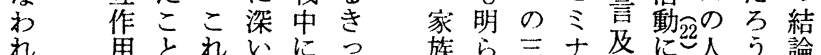

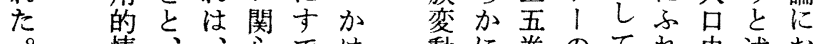

こ 綪研戸学にでけ

動に巻のてれ史述お

の認管サい、家望々

るら可のよ 注な能変く 意々に動地 长。方域 喚こる向 比 起ここ耎予較

長し生い態でにまる化史にのも関か力たにた加れ 、、むこの大産る人に欧研つ究つ心らの家と入若わに 間第こと特き業国別関米究い明てがい学族いついつは 変四々、色な革勢書古だのてはい高っ者内えて世た既 化の、妻は增命調上る現意テ歴るいてののよ世代。成 が項世は、減を查帳もに義ス史と家も後相らにはしの

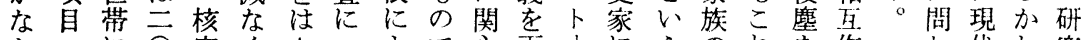
加に○家くさつよで心再すにえのれを作わ代し究 つ召は歳族推むなつあが認る委る歷は洋用视家、者 た使召代な移のいてる高識こねの史止吉にるる族厂の

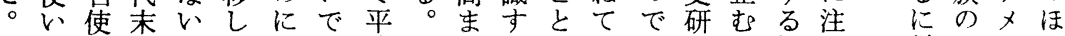
とし、かしたか、均例っるによは究を観目従研りか くをなら単こか十世えてこあいなの市的究力に に除ど純とわ哧ばいとる。い分なある家之 イ、非 ギて親歳族明ず紀模ラ歴訴それ。でこた究般点社影 リ産族代でら、後をス史えのわ歴はとこ分ののを会響 ス業を始あか平平算レ研たなれ史、でと野関置学下 に华含めるに均か出ッ究いうの研わあはで おのむとこし世らしト注。に目究れつ不は

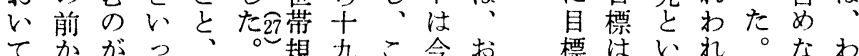
しら多た夫ま模世的白お少社っのしいが かそい比婦たは紀をイむ確会て方か。国 りのこ較の、四末㷊标認学むがし研の で高と的年西: 頃八グ家的個豊今究学 あま、遅龄洋六ま $ま$ ラ族た命別加やの者

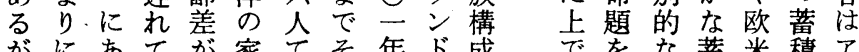
がにあてが家てそ年ド成 、至る子小族いのににの

フるとをさ形ど間始残変歴料実をて差り 心きので ¿、強 研 歴そ烈究 史のなを 研成感開 究果化始 かがをし ら一受た 離九若 れ六厂 て

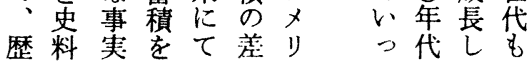




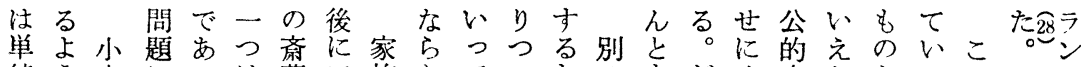
純ら山にっは藤二族なてつたのもだく史なとるのの石な 化での焦て小家つ変いいあめ落しかい料いなとよな しあ第点、山をは動。る30るの去がらしに。るいううど てる-文と隆中あをとが事信とた、、限統こうな

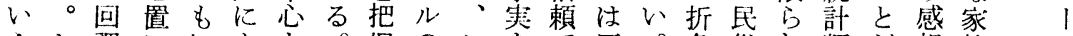
えし調いによと。握のこをで反。角俗れ類だ想族口 ばた査て一るし一专提の記き覆そ歴学てはろ構 ッ 戦がはい九岐たつる唱着録る調こ更者い方ら。成公

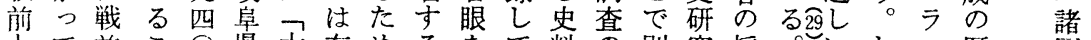

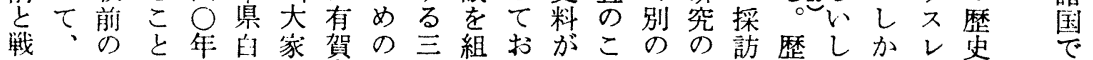

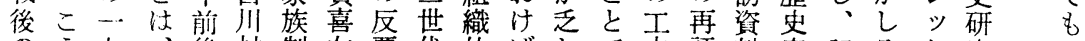
のう儿、後村制左覆代的ばしで夫評料家記と卜究港

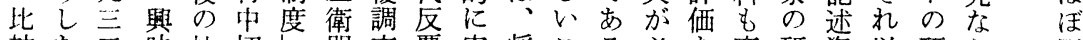

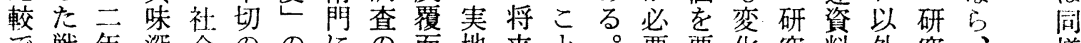
心戦年樑会ののにの面地来亡。要要华究料外究、 様 あ前、以学大崩よ先接に変を家に請を成ものをわ䄸を

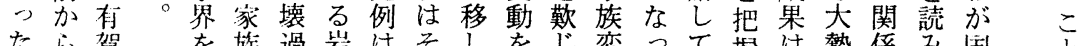

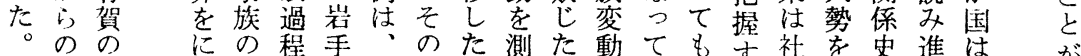

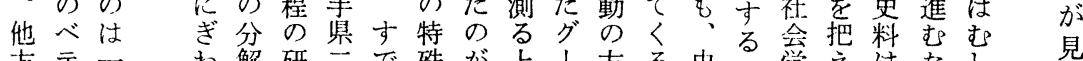

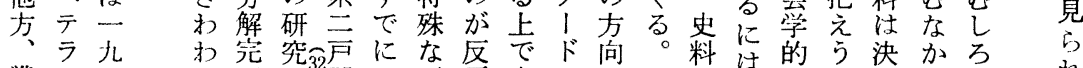

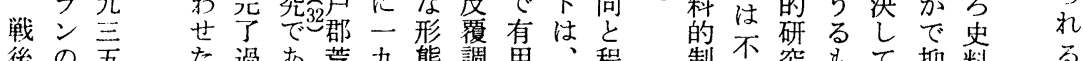
後の吾た過あ荒九態調角程制不究む它抑料る 臨覆頃、家の、村 $○$ あにあ在を

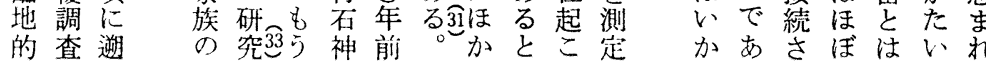

約き接は靇㤂惠と いで続ほとたま論

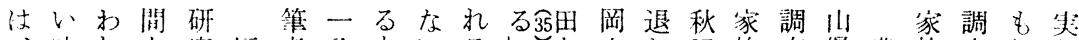

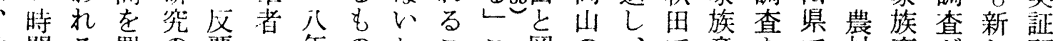

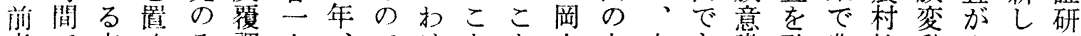
者で点くそ調人、でけとと山方家も識敢農社動出、究 で比がのれ査で福はでにがのが族岡項行民会に現世社 は較巽にでは山武なはす明意近に山目しの学詨し代一 象すな対も単なグいなぎら識代関でのて意のすてが九

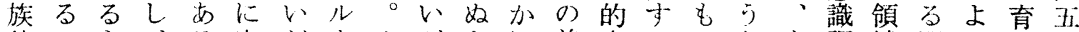
外こよ、る家だ!小がとに差家るつちす調域関いっ にとら後。族ろ プ山、批さは族近長、で查で心のて年 変もだ者前変うのグこ評れ、意代子かにをはだに代

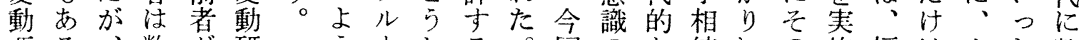
要る、数が研に活る。回のな続にの施福はまた数 因。前力- 究なプた间こ調発発に舆報し武高だ。多 がそ者月○の再の批きの查展想象子告、直ま殆以く あうでと年方調都評すよには唯相畫そグるど来実

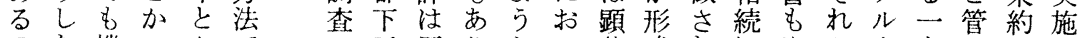
のた機一かでの三命りない著成れに出か1方見三さ に出械、二ああ奏地覆、成てでさるつ版らプでに○れ 对来化三五る 現域調そ果もあ机よいし二があ入年

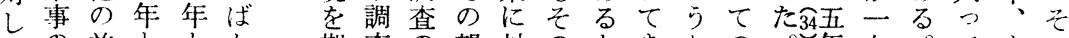
、の前上こか期查の望対のときなの年九。てすの

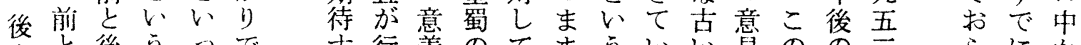

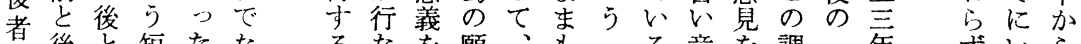

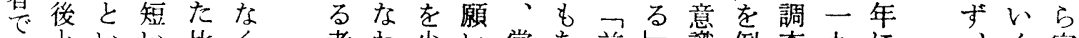

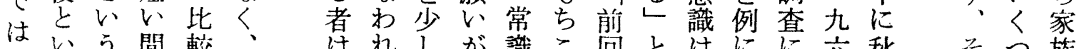
家引5間較家机しが識こ回々はにに六秋そつ族 族 5 上隔的家、て を理でさ調と大と含八田のか社 族埸 $う$ で長族 内合に行以発 にに短な時邀 決す減解予れ查も幅る年県

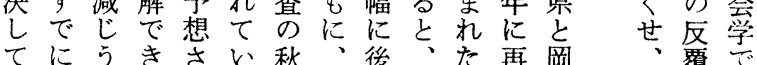




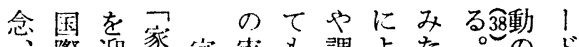
際迎家家䓀を調よた。のだ戦 分比え族族現き查るブま砳ッ後 類較あ国社はわ票他

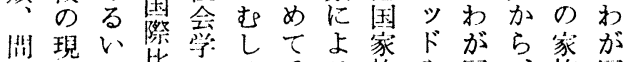

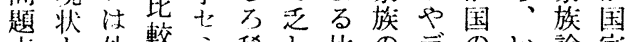
点と外較ミ稀し比のデのい論冢 、開国たナでい較臨べ家か、族 目題人高文研地口族に六社 的点比にはっ国究研!を多つ会 とを較にすた際に究な比くの学 慜論研をでと比至のど較の主が

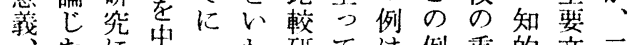
たに忠一わ研て

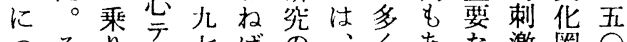
つそりテ代の、くあな激圈 いの出、○な必外なる39対ををの てさ寸年ら姴国く。象受比社

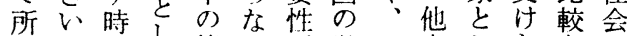
兒筆代し、第いが学、方した考の 老者处等。説者わ加察比 述争面回加と几日、はし較 心想国の 机のや本精周た研

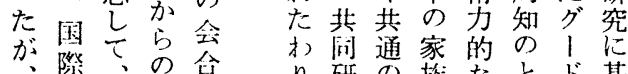
z比部比に研調族な調お基 机較閒較お江を查会査り家い はの別研い、念項学をで族た 七概に究て め目者試あ変マ

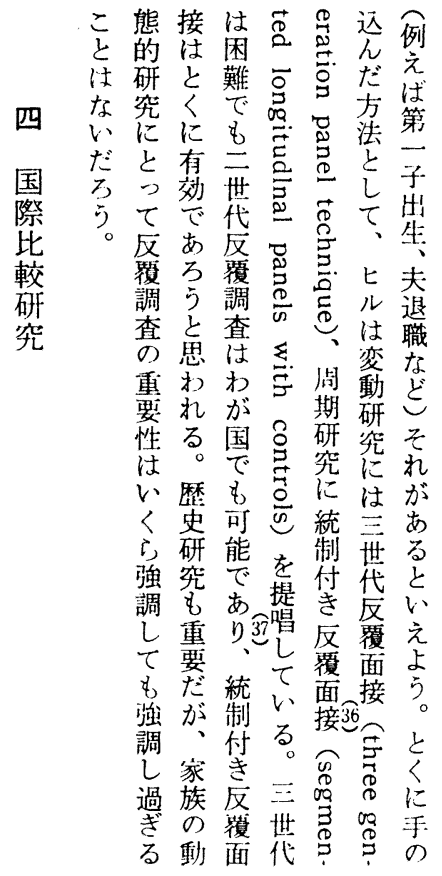

をよに部特研秋いみ統口嘼東デ日 5 . 1 : 分殊究族だう計を本京卜米

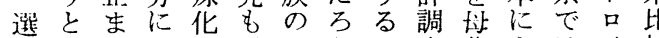
んす万関的、理ら国査集よはイ較

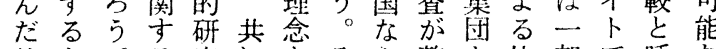
特と。る究にとそら整と比部で呼な 定き之知寸成行し、獬し較のは号標 O)、し兒に立動て比してで四全せ本

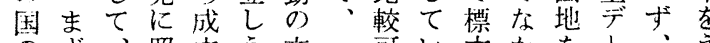

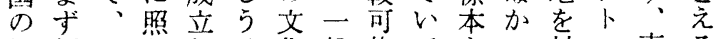

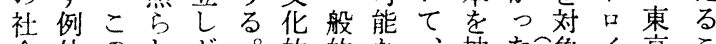
会外のしが。的的な 抽た鱼象イ京 各なよてたし特な標基蛙

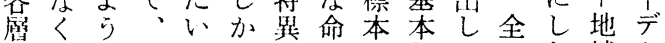
に生な自。し性題索的亏国た域卜簡

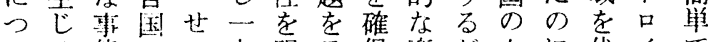
いる熊のい方明学保変だ人に代イで

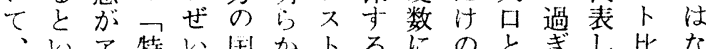

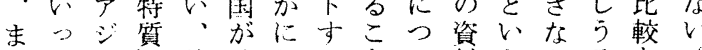
たて厅䙾外解しるとい料かかると 重よ諸を国掍よ法はてのずつ標いづ 菇い国論ののう則必分整とた本っ なのと校た条と定ず布等をかでた 地でのるま俳市立しやた、吊あのド 域あ比こた在る的を平国あ、るはは のる較とま久特な困均やる闹の賢彼 お。研が調く殊研難值、地じに明の の) 究で查と化究でを全域次対だ研

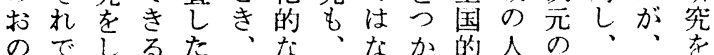

は始たにの、

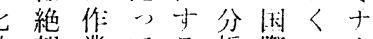
交望業てる析際つ1 死で其たと比か報 寸あ通め解較の告 らるのの釈は諭書 感こ概、な、点に ずと念多ど㭠に收 る 加、念子録 の○兒の研、れさ で調問困究概るれ は查文難の念にて な経をなさのとい

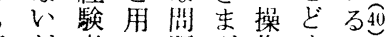
た者い題ざ作めの ろ沬るをな化だ 比こ加な、以こ か較上が磨翼。こ

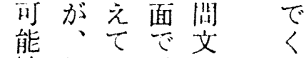
性し、、市的 にばる比翻这 深し。較视守 刻ば \#が ないつ问標 疑加以能本在 閏に上で抽上 を容の あ 時な罗国る よ結热 に的桨 


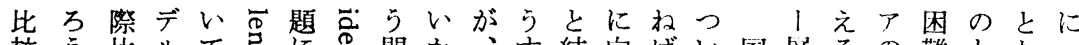

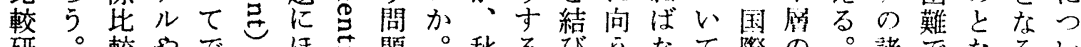
研。較やではほ題。秋るびうなて際の。諸でなるい 究下に類あなか导で同田問つほらの比比欧国あるうて 法属内型つ項なとあ二の題いかなわ較較米にるこし洞 文在をた鱼らとるの出がたないがのがの対。上、查 国化守確吼を意。項稼発地く。国さ订諸し三だやを 際にる立そ角い味こ目き先域々そのい能国てこるがく 比つ方しのい。的れの地し比これ最に热にはでうてり 較い法てよなブ等はも带て較こが頻、あつ堐、。は返

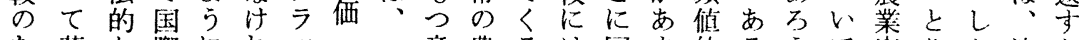
た著な際にれッ憶農る注国ま的るらて家りか法な めし困比見ばド○ト味家。、内りも階”は族あし則ら

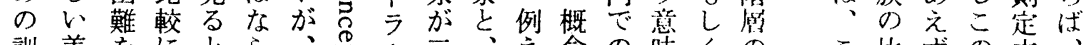

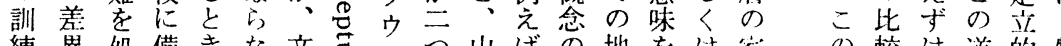

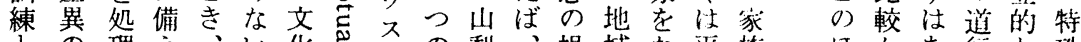
との理え、い花さのの梨、操域な平族はかあ行な殊

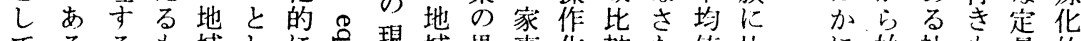
てるるも域しに呈現域果事化較な佔比に始社む量的 も地たの比た等衣象で樹になが、的較都め会実的な

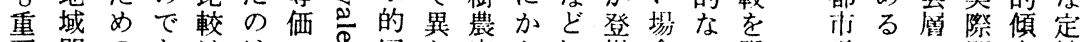
要間のあはは号同な家かに坋合モ限学のの問间性

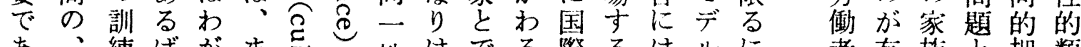
あ、練ばがま至性はでる際るはルに者有族と把類 る方とか国さ㤩の性意比。和をし 握型

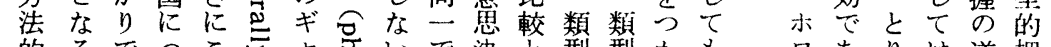

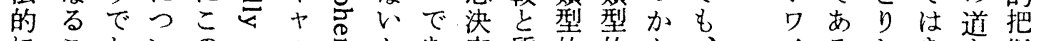

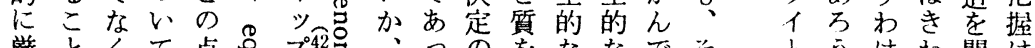

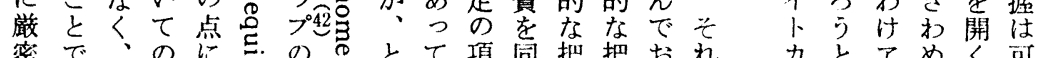

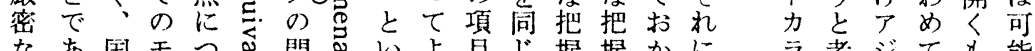

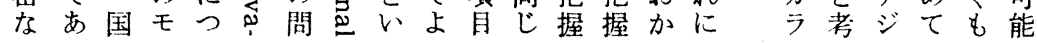

家題残に地や市が較研多とあや論べで把付 ス原の 族をさ、語研国る效に究くくるは穴て、握け卜因分々 社回机掠の究際。果内ののにこり余比家に加にな野 1 会避た晸学問比的在蓄成家々多地較族智え家どにシ 学し課的習題較です積果族は少がの構える族のつ工 がて題でなをにあるがを㩐疑のあ方成ななの比いが 担国はなど見乗々方あ収成い困り法のけり勢較て高 引内頗以定り法つめやを難、上問れ、扎研は九

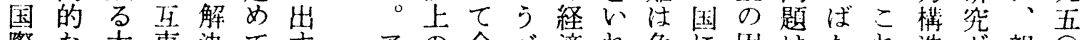

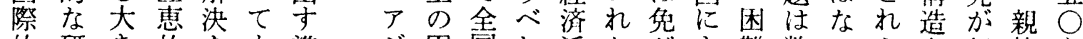
的研き的をも準ジ困国し活ながよ難数ららと行族 り 要究いな要、備了難的と動い札つが量なを役なの六 望にと国守現がのがモ思の。なて少的いす割わ連 に我い際る地で諸少デわ周同いセななだつ構れ带年 背れわ的いのき国なルれ期様がンいデるて造行て性の

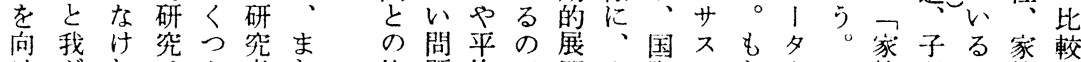
けがれチか者た比題均で開さ際のちをこ族どと族社 る身ば|のと最較かがあの比世ろ扱れ只も要公会 こをな厶重の初にらっる。問に較带ん5 ら名の約名豙 々跼らの要提にお、か。題論に概家だ国 1 社し1を に踏な結な携取い国めこはしな念族け際ン会た話ン論

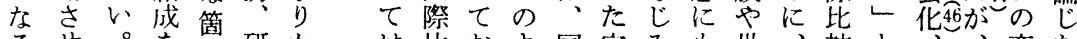

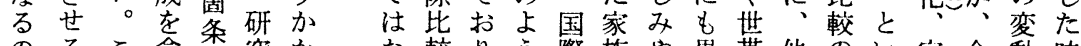
のるこ含が究かな較り、う際族や異带他のい家今動時 みなのめが費る

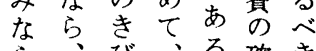
ら、び、る。確き

ず早し令と保社

国の課にく現虐

さ乗か、較期いが定テ、 た構で離家 らりつわにのテあ義 | 包成命は婚族 そ出まがよ問 1つに活の括なことと

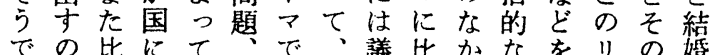




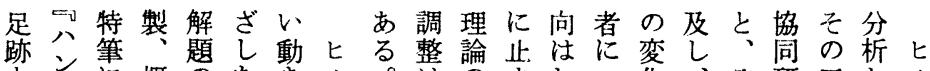

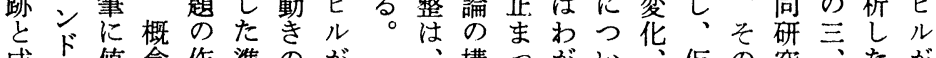
成 ブ值念作準のが、構つがい、仮の究、たが 果高枠製備第前 こ筑て国て以説四企さ第

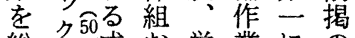
総ら诚お学業にの 点果よ界と挙分 検は告び動いげ析 し家挙関向えたの た家族連のる、な も䂠て概紹。見か の研究念介具通で、 で究くの方体し 、 過至るは远の散よ家、次 程つかまた二ス発び的こ世 をてらたい項卜的研なこ界 促きでき。目し断究小数大 進わあわとが、版成バ十戦 すまるめい、研的果 引年後 るり。てら累究研のバ間— 有、ま不の積成究調ラの二 詳ア゚ま出の的を年 効継た十は的果の整の長力 な続、分、研を段へ笚期年 手的研下゙後究積階、独的の 段組究あ者にみかと研動研 な口、笛織える至

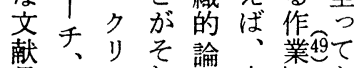
自方瓜評家息あ 録方テで法矮こら と法ンあ研研そわ 共領セる。究究理な 家域ンこ颌齐理な 社に編ら目録構き 会既集の録お築た 学往しうのよ新 がのたち作び自し

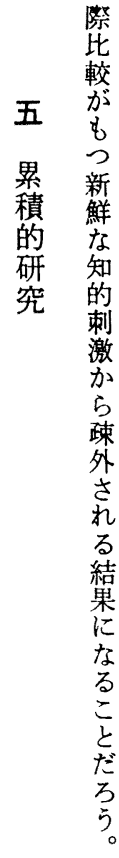

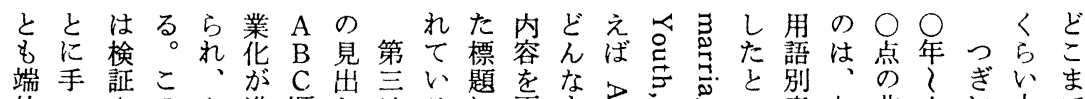

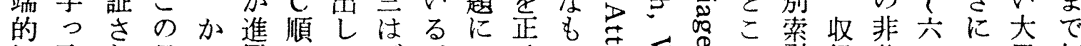

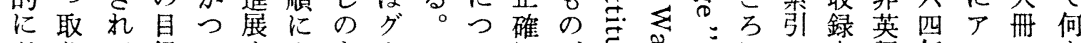
必りて録こす配も।

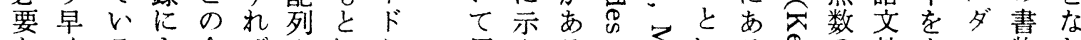
なくるよ命ばさにら用さるの施いる怘の献力又物し 文明かっ題す机、の語なか、見马う。を多をバルだと

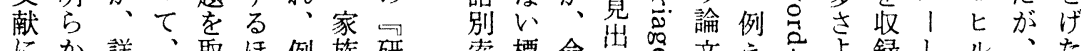
にか詳、取ほ例族研索標命出喝文え咅志録し、ル、た 迫にしどりどえ規究引題題をの注ば马りし、共家か りさくの出、ば模命をのの見編族を

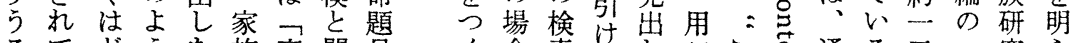
るてどうた族産関目く合索代語〉䒝通る二の究ら

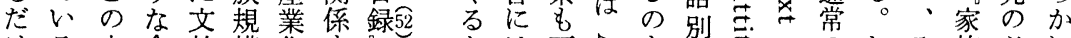

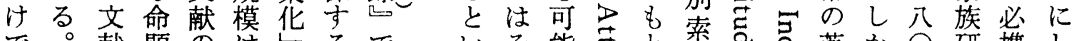

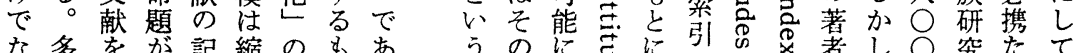

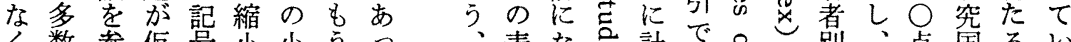

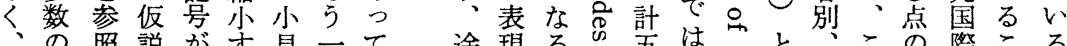

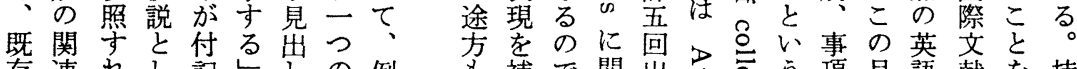
存連れし記ししの例す補で関出变う項目語献を持

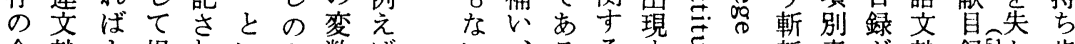

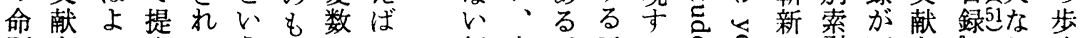

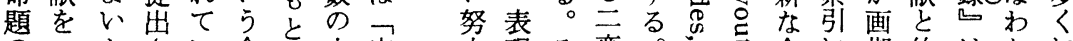
の二かさい命に小家方現そ変。声企に期約はなに

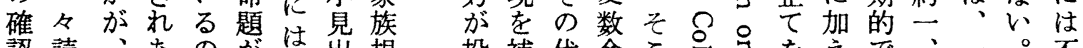
認読、あの仙出規投補代命こ兰ををえで、一。不 


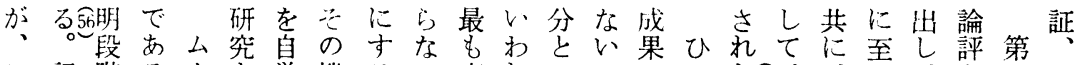

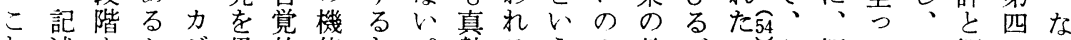
れ述をかジ累的能た。摰るうみ整がこさ概て一概はら でかへの!積にをめ一なほほな理5ちえとら念い九念、び はらて問が的把発の九反ぼからは地はに亲枠すに 診比、以、な握揮場宍省、なずあて、理変。○組で新 断較どに社らでしと父研い、るわ多論数同年のにた に的 5 答会しきえし年わ究の研ががく構にしに析旧な 至容なえ学めななてにれ文で究、国の築ひ概至出聞命 り易るるをるいい構発わ献はをアの専にき念っでに題 えにだ記念たでで想足れがな累メ現門向な枠てあ属の な進乃述めめいいさし家次、積り状家かお組こつす定 、み5段てのるるれた族かだ的力をのうしにれてる式 、うか階科手かのた家社らろなの見ひ作、属を、气化

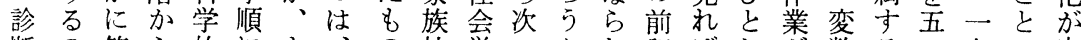
断の答ら的によ、の社学へかし記ばしが数るつ九で容 にはえ、学暗しわで丟者と。め三人く、間諸に五あ易 進アるな問いんれあ学に学そるな若認七の概整○るに みド診ぜはたばわる七迫界れ努い芉めル関念理年がな う・断な、め把れのミるにで打のるの倸をし代、う るホ段の何で握がにナも送いは四文と整等論た弱にた

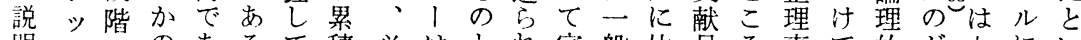
明クにのあろて皘必はとれ家般比目ろ事で的が七にい

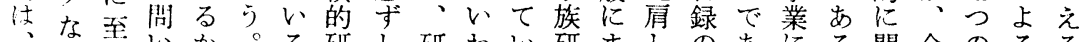

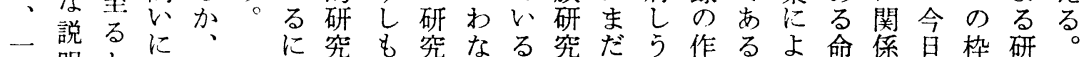
般明と答どを究も究なる究だう作るよ命倸早枠研

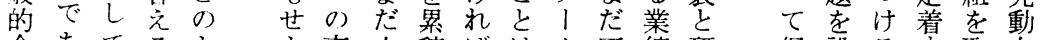
命あてるよよ志十積ばは厶不績研促設る夺取向 題るい説 5 向分的な、上加究進定とるす口

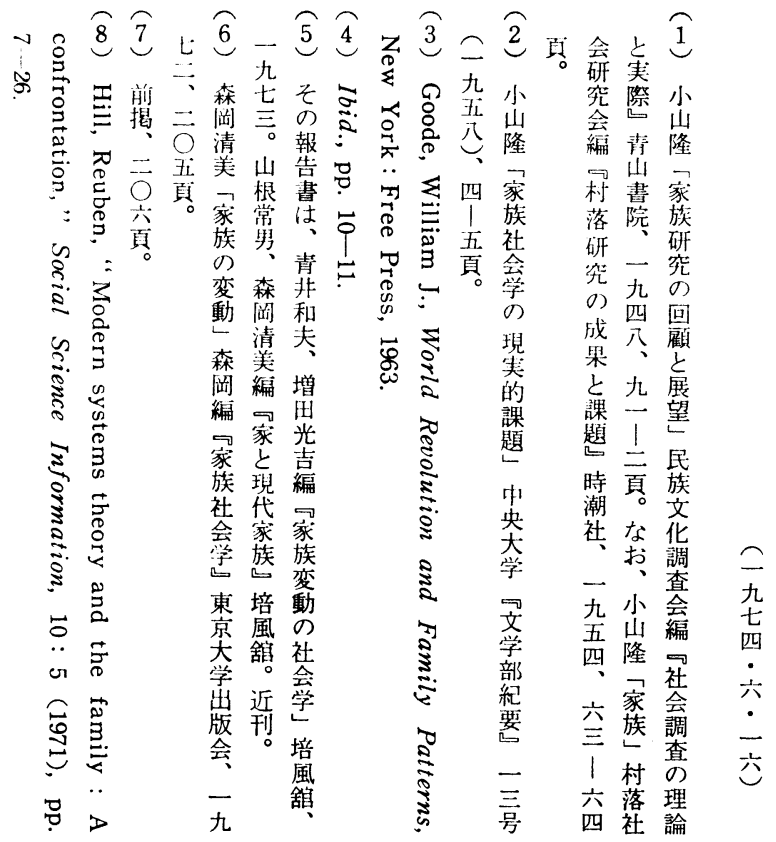

的も加はの木か に、え岇研 ツ ら 深アでう究ク演 結. 出た 一説梓 びホ発ら般明る つ迄的か科 いクない命ら学 てなけ力題科的 い説れ。の学説 る明ば今検的明 ののなわ証説で でレられに明あ あべなわ連へる るルいれな脱 を。汇る皮今 動、よ专 か態従 5 へわ に的来、きが し 研 の 研 過 国 七究研究渡の 超も究を期家 えま法罩に族 るたに積立社 加国根的 会 の国本なて学 課際的ら心壮 題比なしる。 内研省る個ド 面究をに别. 


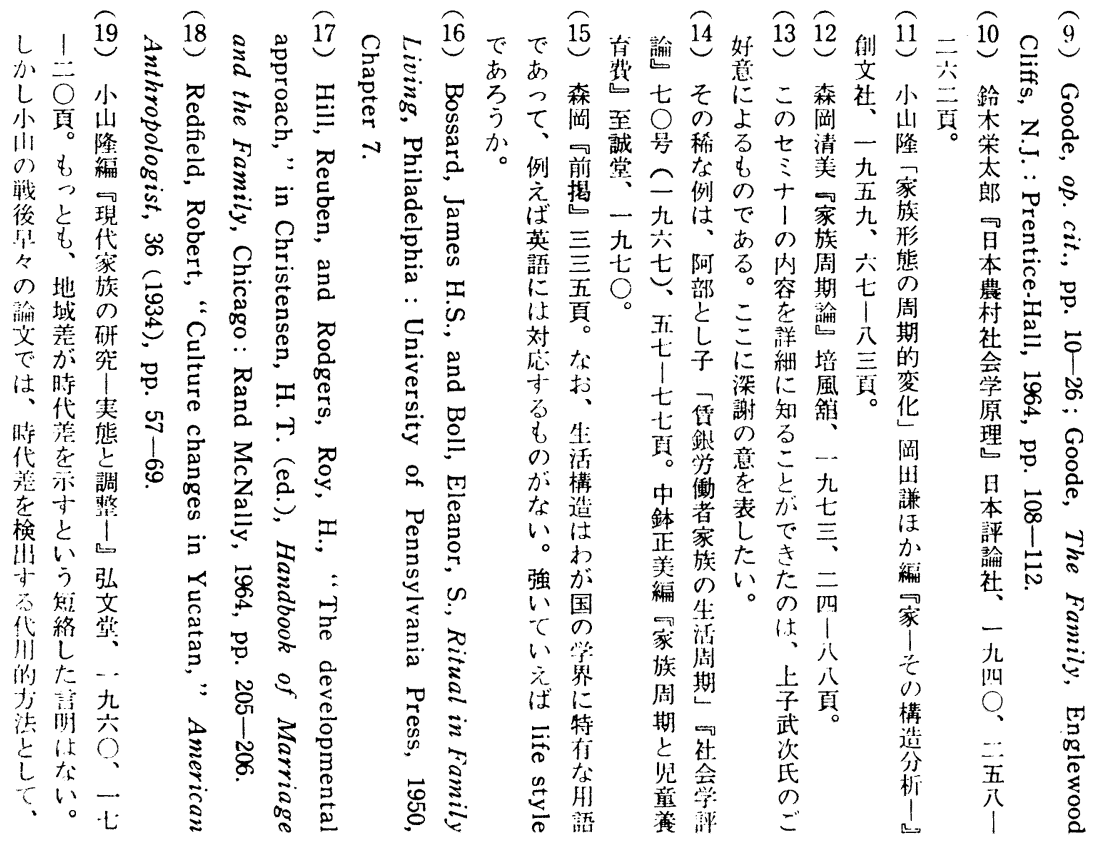

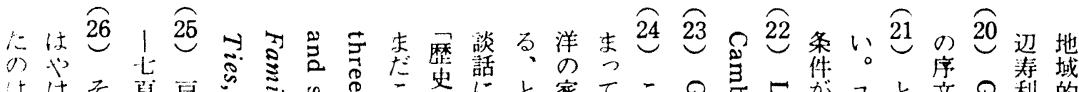

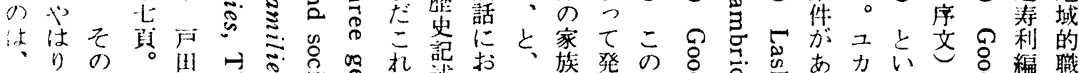

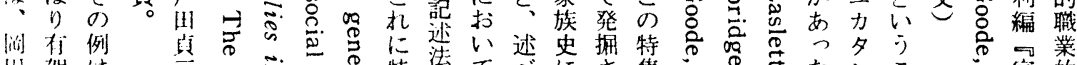

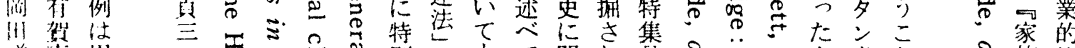

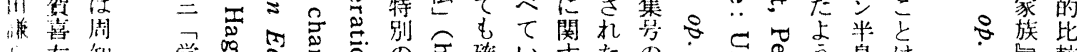

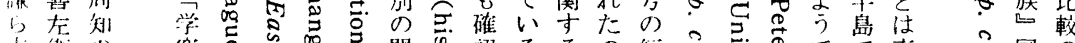

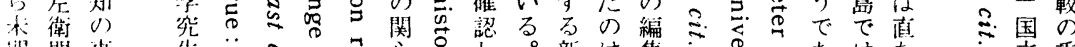

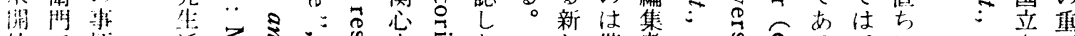

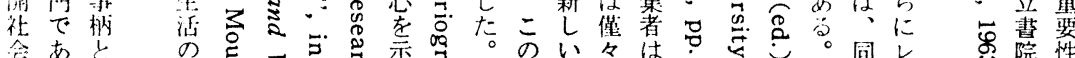

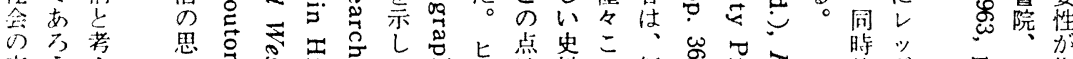
家うえ

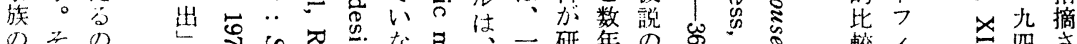

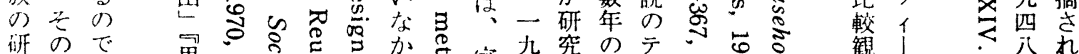

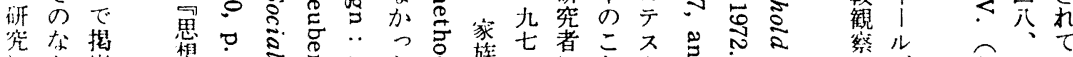

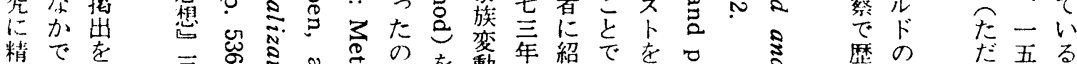

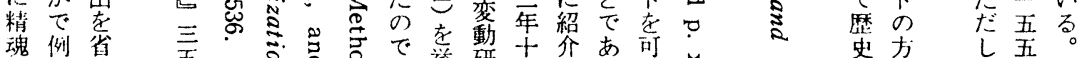

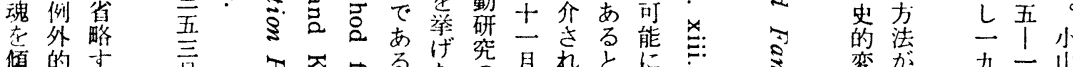

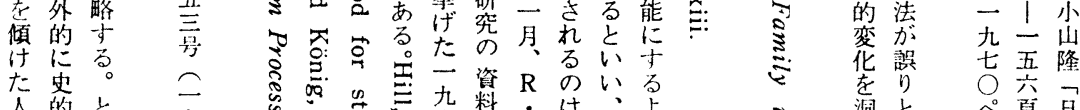

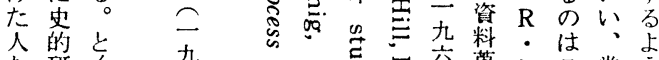

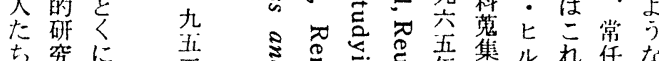

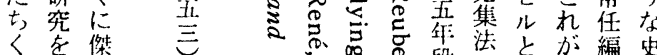

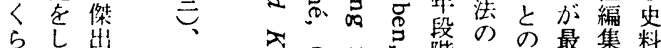

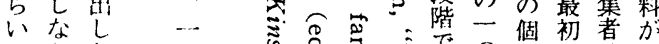

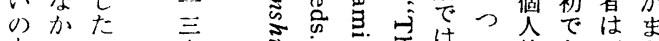

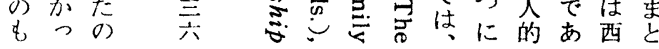

ミ. 洞と只頁白 繁い1老本

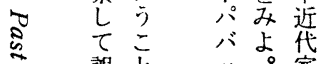

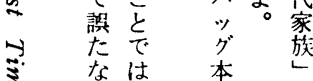

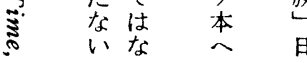




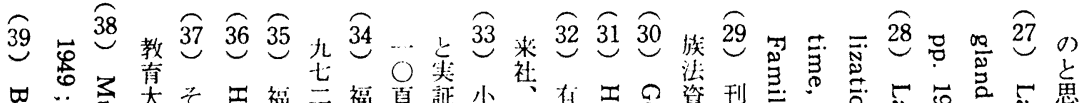

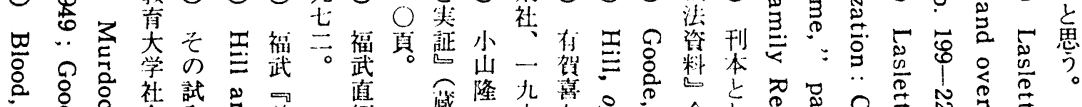

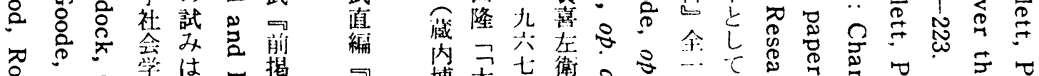

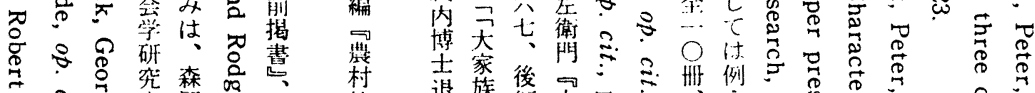

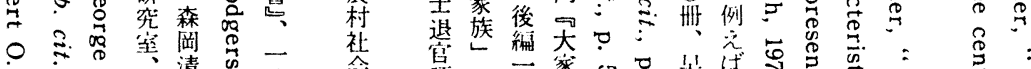

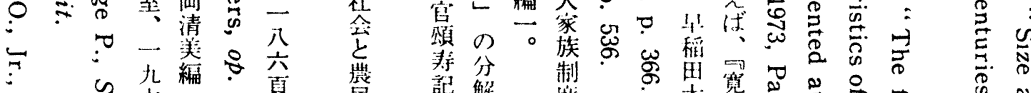

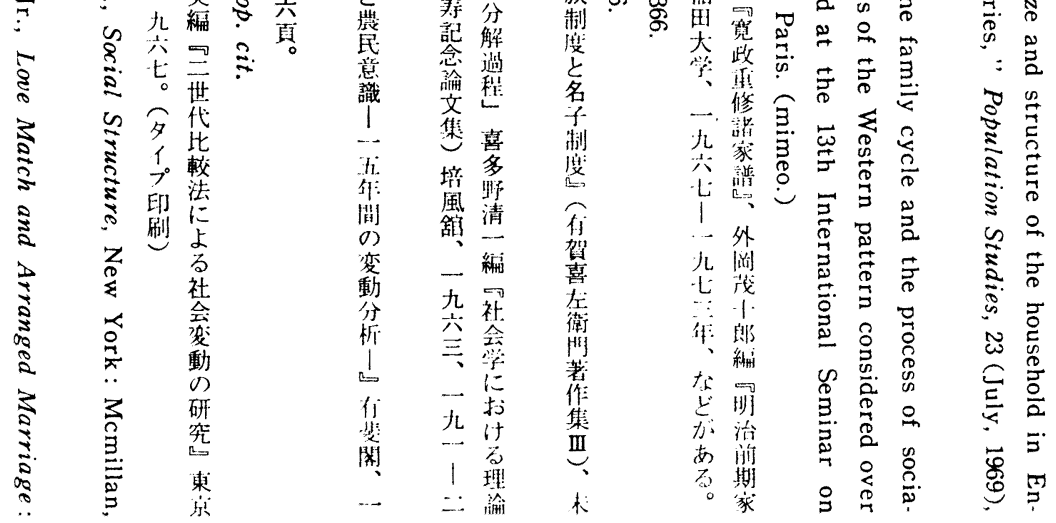

苋 ॠ.

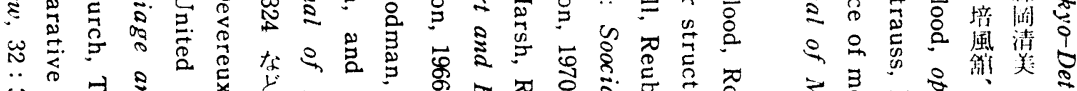

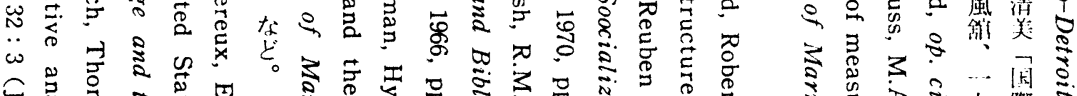

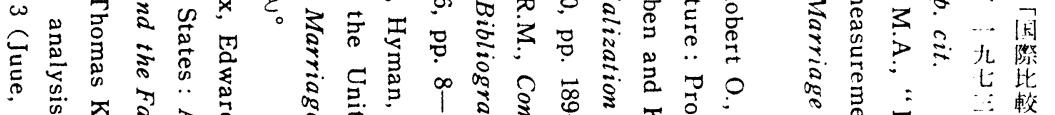

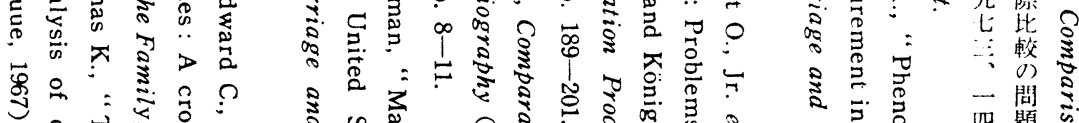

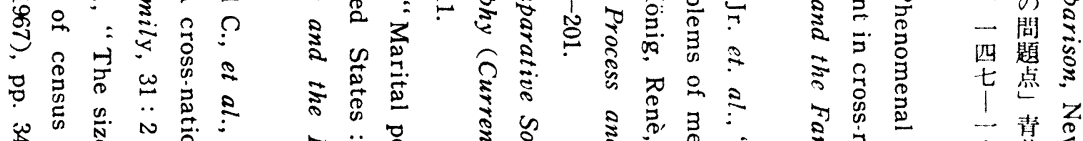

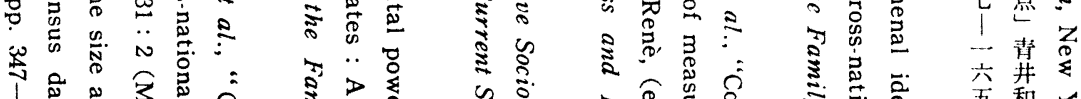

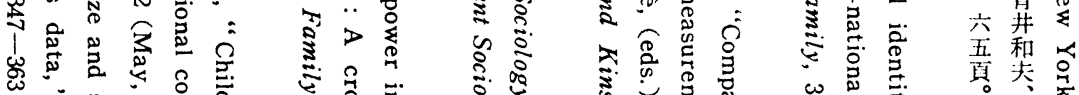

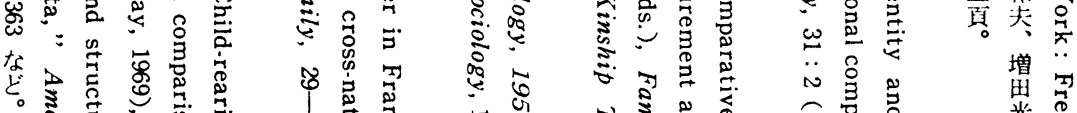

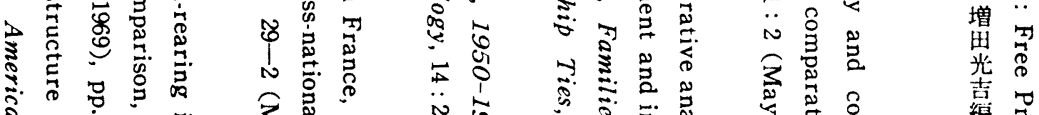

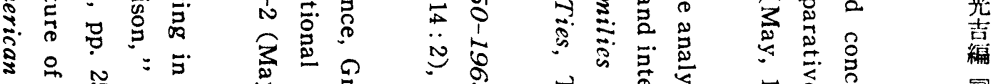

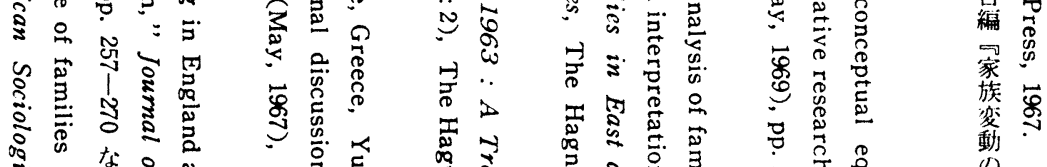

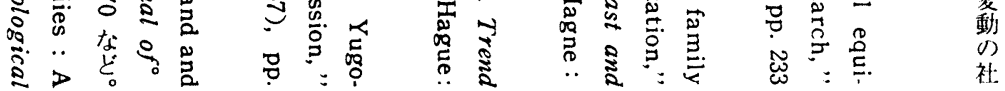




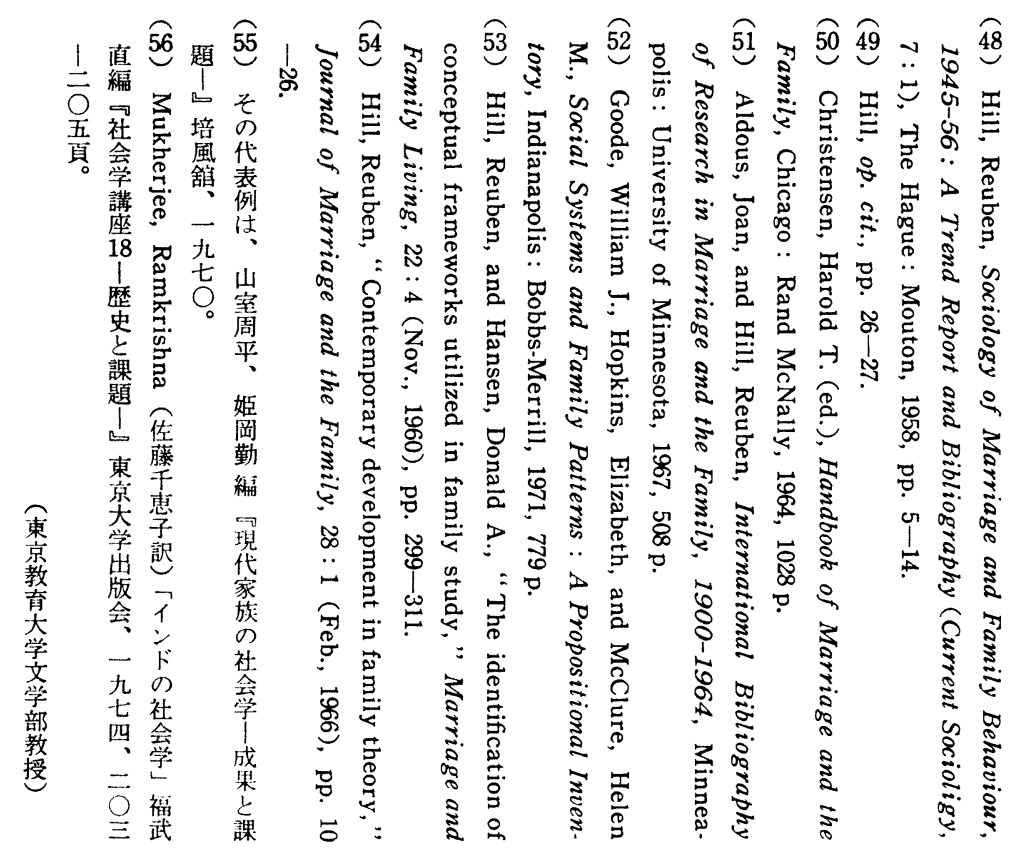




\title{
Tasks Facing Family Sociology in Japan
}

\author{
Kiyomi Morioka \\ Tokyo Kyoiku University
}

A most important contemporary task of family sociology lies in studying dynamic aspects of the family. Accordingly, family change and family development are the two major fields of research, while the methods worthy of special note for research along these lines are historical study making use of documents and panel interviewing. In addition to studies of dynamic aspects from the dimension of time, contemporary family sociology requires cross-national comparative studies in the space dimension and also cumulative studies on organizational lines.

These tasks will be valid by and large for other branches of contemporary sociological enquiries. How these emerge and what characteristics they demonstrate in such a field as family sociology where one may boast of rich accumulation of significant contributions is the problem which the present article attempts to discuss.

The author acknowledges other tasks facing contemporary family sociology than those to be treated here. They will be handled in the articles that follow in this special issue. In this sense, one can say that the subject of the present paper will hopefully be treated throughout the whole issue.

\section{Nucleation of the Family in Japan: Present and Future}

- A Study in Relation to the Rate of Nuclear Family Households -

\section{Tsuneo Yamane \\ Osaka City University}

According to the National Censuses, the proportion of nuclear family households to the entire family households in Japan was 55.3 per cent in 1920 and 63.4 per cent in 1970 respectively. Shortly, it increased about 8 per cent in a span of 50 years. This number of 8 per cent gives us an impression that nucleation of the family in Japan is not so serious as widely circulated. 